\title{
Recognition of Gendered Experiences of Harm at the Extraordinary Chambers in the Courts of Cambodia: The Promise and the Pitfalls
}

\author{
Diana Sankey
}

Published online: 23 February 2016

(C) The Author(s) 2016. This article is published with open access at Springerlink.com

\begin{abstract}
Forty years after the beginning of the Khmer Rouge regime, the recent Trial Chamber judgment in case 002/01 before Extraordinary Chambers in the Courts of Cambodia (ECCC) has provided legal recognition of the devastating violence of the forced population movements. However, despite the undoubted significance of the judgment, it represents a missed opportunity to more fully reflect issues of gender. The article argues that in order to capture the plurality of gendered experiences it is necessary to foreground a social understanding of harm. Drawing on civil party oral testimony, the article begins to surface gendered experiences of the social harms of familial separation and starvation of family members, harms that have often remained silenced in international criminal law. In doing so it seeks to contribute to emerging feminist discourse on broader gendered harms and illustrates the need for further scrutiny of the approach of the ECCC.
\end{abstract}

Keywords Gendered harm - Extraordinary Chambers in the Courts of Cambodia . International criminal law · Forced displacement

\section{Introduction}

Feminist research has increasingly highlighted the need to look beyond a focus predominantly on sexual violence and to explore other gendered experiences of armed conflict and political repression (see, for example, Franke 2006; Harris Rimmer 2010; Ní Aoláin et al. 2011; Lemaitre and Sandvik 2014; Sankey 2015). Indeed, recent research has begun to address the gendered nature of socio-economic violence and of forced displacement (Meertens and Zambrano 2010; Lemaitre and

Diana Sankey

d.s.sankey@ljmu.ac.uk

1 School of Law, Liverpool John Moores University, Redmonds Building, Liverpool L3 5UG, UK 
Sandvik 2014). Further research is now needed to theorise broader gendered harms and analyse how such harms are treated in international criminal tribunals. The article focuses on case 002/01 before the Extraordinary Chambers in the Courts of Cambodia (ECCC), a case that has so far not been addressed by feminist scholars, as it did not include crimes of sexual violence. However, while the case does not at first sight involve issues of gender, a more detailed exploration begins to open up the subtle nature of gendered experiences.

The ECCC is a hybrid tribunal, involving a mix of international and Cambodian law and international and national personnel. It was established in 2004 by a bilateral agreement between the United Nations and the Cambodian Government in order to prosecute "senior leaders of Democratic Kampuchea and those who were most responsible for the crimes and serious violations of Cambodian penal law, international humanitarian law and custom, and international conventions recognized by Cambodia, that were committed during the period from 17 April 1975 to 6 January 1979". ${ }^{1}$ The crimes within the jurisdiction of the Court include genocide, crimes against humanity and war crimes, as well as certain crimes under Cambodian law perpetrated during the Khmer Rouge regime. The Court is noteworthy for its innovative system of civil party participation, which allows admitted victims to participate as civil parties in a case, and for its more inquisitorial approach. Following the conviction of Kaing Guek Eav (alias Duch) for crimes related to the infamous s-21 prison, in case 001, the Court is now proceeding with its second case, which is far more complicated and involves a wide range of offences perpetrated throughout Cambodia during the regime. ${ }^{2}$ Case 002/01 involved a small part of this second case, centred on two of the phases of the forced population movements, including the mass removal of the population from the capital, Phnom Penh. ${ }^{3}$

Drawing on feminist theories of the social nature of harm and on insights from civil party oral testimony, the article critiques the narrative produced by the judgment in case 002/01 (for discussion of social harm see West 1997; Conaghan 2002; Ní Aoláin 2009). ${ }^{4}$ While the centrality of the forced population movements to the case provided the ECCC with considerable scope for recognising lived experiences of forced displacement and gendered harms, such an opportunity was not fully realised. The article focuses on harms of familial separation and the starvation of family members stemming from forced displacement; harms that have received limited scholarly attention, but may be central to gendered experiences (Ní Aoláin 2009, 234). It argues for the importance of foregrounding a social

\footnotetext{
${ }^{1}$ Agreement between the United Nations and the Royal Government of Cambodia Concerning the Prosecution under Cambodian Law of Crimes Committed during the Period of Democratic Kampuchea, 6 June 2003.

${ }^{2}$ Co-Prosecutors v. Kaing Guek Eav alias Duch, Trial Chamber, Judgement, Case File No. 001/18-072007/ECCC/TC, 26 July 2010; Co-Prosecutors v Nuon Chea, Ieng Sary, Ieng Thirith, and Khieu Samphan, Closing Order, Case File No. 002/19-09-2007-ECCC-OCI, 15 September, 2010.

${ }^{3}$ It also included crimes perpetrated in relation to the Tuol Po Chrey execution site. Co-Prosecutors $v$ Nuon Chea and Khieu Samphan, Decision On Severance Of Case 002 Following Supreme Court Chamber Decision Of 8 February 2013, Case File No 002/19-09-2007/ECCC/TC, 26 April 2013.

${ }^{4}$ Co-Prosecutors $v$ Nuon Chea and Khieu Samphan, Trial Chamber, Judgement, Case File No 002/1909-2007/ECCC/TC, 7 August 2014.
} 
understanding of harm that reflects human relationships and connectedness in order to open up gendered experiences.

The article is based on a reading of the testimony of twenty-five of the civil parties in the case who directly discussed their experiences of phase one and/or phase two of the population movements. ${ }^{5}$ The testimony was researched through the ECCC website, which provides day-to-day transcripts as well as videos of the testimony. The research also draws on semi-structured interviews with Englishspeaking lawyers and court personnel conducted during a visit to the Court in June 2014. ${ }^{6}$ Clearly, there are limitations to this research given its use of a small range of oral testimony, as well as possible problems of translation, which the article acknowledges. However, the aim is not to provide an overview of the harms of forced displacement experienced in Cambodia, but rather to begin to listen to the experiences of these civil parties and to examine the judgment in light of such experiences. A reading of the civil party oral testimony provides a counterpoint to the narrative of the judgment and generates insights into gendered experiences beyond sexual violence.

The first part of the article contextualises the treatment of gendered experiences of harm in case 002/01 by outlining the limited gender awareness at the ECCC and the potential significance of civil party participation. The second part highlights the centrality of social understandings of harm to capturing gendered experiences and opens up the harms of familial separation and starvation of family members. The final part focuses on the treatment of the forced population movements in the Trial Chamber judgment. Drawing on the civil party testimony, it critiques the lack of contextualisation of the harms in the judgment in relation to Cambodian society and the silencing of diverse gendered experiences. In what follows, the article aims to contribute to feminist research by placing theories of social harm in relation to lived experiences in Cambodia, and to provide a basis for further scrutiny of the narratives produced by the ECCC in the remaining parts of case 002 and subsequent cases.

\section{Contextualising the Treatment of Gender at the ECCC and the Background to Case 002/01}

Despite increased recognition of the need for gender-sensitivity in international criminal law, the ECCC initially failed to investigate crimes of sexual violence (Studzinsky 2013). Unlike the International Criminal Court (ICC), the ECCC does not have a gender advisor and there have been criticisms of a lack of gender balance in its investigative personnel (Killean 2015). While the Law on the ECCC includes rape as a crime against humanity, it does not mirror the more extensive approach of the Rome Statute of the ICC, and thus does not explicitly include sexual slavery,

\footnotetext{
5 While there were 31 civil parties who gave oral testimony before the Court, the research only draws on 25 of the civil parties, whose testimony directly related to experiences of the two phases of the population movements.

6 The research visit was funded by a Society of Legal Scholars Research Activities Grant. The interviews were conducted in private at the Court and interviewees are referred to anonymously in the paper.
} 
forced pregnancy and other comparable forms of sexual harm. ${ }^{7}$ Sexual violence other than rape therefore will need to be incorporated under the other crimes against humanity, namely 'other inhumane acts'. The limited focus on gender issues at the Court has inevitably shaped its treatment of harms of forced displacement in case 002/01. Despite some shifts towards acknowledgment of sexual violence at the Court, this has yet to be comprehensive and it seems likely that broader gendered experiences will continue to be obscured unless there are shifts in the ECCC's approach (see Killean 2015). It is therefore important to outline this broader context of a lack of gender awareness and the possible impact of civil party participation, before reflecting on the background to case 002/01.

\section{Civil Party Participation and Gender-Awareness at the ECCC}

Although victim-oriented approaches form an increasing trend in international criminal justice, as evident in the approach of the ICC, the hybrid nature of ECCC allowed it to develop a distinctive and (initially) more comprehensive approach to the role of victims/survivors (McGonigle Leyh 2012; Hoven 2014; Elander 2013). While the ECCC statute did not include provisions on victim participation, the civil law basis of the Court allowed the judges to develop and tailor the domestic law practice to the particular context of the ECCC. Victims at the ECCC can become civil parties in a case, provided that they can link the harms suffered to the crimes charged. ${ }^{8}$ Civil party status provides the right to participate as a formal party in the proceedings, with rights that are, in theory, similar to those of the prosecution and the defence. This therefore goes beyond the rights provided by the victim participation procedure at the ICC (Stegmiller 2014). Admitted civil parties have the status of legal parties to the proceedings and can seek collective and moral reparations. ${ }^{9}$ In addition, victims can submit complaints to the Co-Prosecutors, which are taken into account when deciding whether or not to prosecute.

Significantly, women have constituted a majority of the civil party participants. The gender ratio of admitted civil parties to case 002 (those accepted by the Court as having met the criteria for admissibility) is 2371 female out of a total of 3867 participants; meaning that $61.31 \%$ are women. ${ }^{10}$ There are many complex factors influencing the high numbers of female civil party participants before the Court (interview with a civil party lawyer, 30th June 2014). One significant factor may be the higher number of women surviving the Khmer Rouge regime, since men were targeted more frequently for direct killing (Boua 1982). Whatever the reasons, the high female participation rate raises the potential for women's experiences to be voiced at the ECCC. Indeed, in case 002/01, seventeen out of the twenty-five civil

\footnotetext{
7 Law on the Establishment of the Extraordinary Chambers, with inclusion of amendments as promulgated on 27 October 2004 (NS/RKM/1004/006); Rome Statute of the International Criminal Court, A/CONF.183/9, 17 July 1998.

${ }^{8}$ Rule 23 bis (I) of the ECCC Internal Rules.

9 ibid.

${ }^{10}$ Statistics received from the Victims Support Section of the ECCC.
} 
parties who gave oral testimony on phase one and two of the population movements were female.

Civil party participation has played a role in beginning to challenge the lack of gender awareness at the ECCC, particularly regarding the Court's treatment of sexual violence (interview with civil party lawyer, 30th June 2014; SáCouto 2011). The preliminary investigations at the Court did not include sexual violence or other gender-based harms. This was in part due to the Court's acceptance of Khmer Rouge claims that sexual and gender-based violence had not been prevalent; claims that have been increasing challenged by survivors and civil society organisations and shown to be false (Natale 2011; Nakagawa 2008; Ye 2014; Studzinsky 2013). While in case 001, Kaing Guek Eav was convicted of one incident involving rape, attempts by civil party lawyers to include further counts of sexual violence failed. ${ }^{11}$ As Studzinsky critiques, "although the ECCC was established after the ad hoc tribunals and the ICC, the ECCC seems to be far behind these courts with regard to the investigation of sexual crimes" (Studzinsky 2013).

Civil party participation has allowed for the contestation of the initial exclusion of rape in the context of forced marriage, leading to forced marriage being charged in case 002. Nevertheless, the charges do not extend to rape outside of forced marriage, meaning that many other forms of sexual violence will continue to be silenced (de Langis 2014; Wallström 2012). ${ }^{12}$ It may be that civil party participation will promote greater gender awareness in cases 003 and 004, provided these cases come to trial. Indeed, the International Co-Prosecutor has more recently filed submissions requesting investigations of sexual violence both inside and outside of forced marriage in case 004 and inside of forced marriage in case $003 .^{13}$

While civil party participation therefore provides possibilities for survivors to have a greater input into proceedings, this potential is dependent on the Court hearing women's and men's diverse voices and reflecting these experiences in a sensitive and meaningful way (SáCouto 2011). Indeed, the space for gendered experiences to be voiced receded in case 002 due to adaptions to the procedures on civil party participation. The large number of civil parties in case 002 has undoubtedly posed logistical issues for the Court, particularly concerning representation (see Sperfeldt 2013). These concerns led judges to revise the procedures in order to simplify and restrict participation (Stegmiller 2014; Hoven 2014). Civil parties were no longer able to participate individually in proceedings but had to do so as a "consolidated group", with two Lead Co-Lawyers given responsibility for coordinating the approach of the civil parties and representing

\footnotetext{
11 Co-Prosecutors v. Kaing Guek Eav, n 2.

12 Co-Prosecutors $v$ Nuon Chea and Khieu Samphan, Trial Chamber, Decision on Additional Severance of Case 002 and Scope of Case 002/02, Case File Dossier No. 002/19-09-2007-ECCCITC, 4 April 2014, E301/9/1.

13 ECCC, Press Release, 'International Co-Prosecutor Requests Investigation of Alleged Sexual and Gender-Based Violence in Case 004' (24 April 2014), at http://www.eccc.gov.kh/en/articles/internationalco-prosecutor-requests-investigation-alleged-sexual-and-gender-based-violence; Press Release, International Co-Prosecutor files Supplementary Submission in Case 003 (4 November 2014), at http://www.eccc. gov.kh/en/articles/international-co-prosecutor-files-supplementary-submission-case-003 (1 December 2015).
} 
Civil Parties before the Trial Chamber and Supreme Court Chamber (Hoven 2014). As such, there has been a move away from the original vision of civil party participation towards a more circumscribed model, where victims are no longer truly 'parties' in the case (Hoven 2014). In addition, there have been significant resourcing issues, resulting in reliance on pro bono civil party lawyers, which may affect the quality of representation and the time lawyers are able to spend with civil parties.

As with other criminal tribunals, and despite its more inquisitorial approach and structures, the ECCC necessarily restricts and shapes testimony to meet the needs of the criminal justice process (see more generally Dembour and Haslam 2004). Significantly, the Trial Chamber did allow four trial days of victim impact hearings, during which fifteen of the civil parties could testify more broadly to their suffering experienced. ${ }^{14}$ Although still subject to time constraints, these sessions provided an important space for survivor testimony and opened up some of the physical, psychological and social harms experienced. The research in the article is based on exploration both of the civil party oral testimony during segment three of the trial (focused on the forced population movements) and the civil party oral testimonies during the victim impact hearings. While the article cannot do justice to the enormity of the harms discussed, it seeks to listen to the voices of these civil parties, in order to open up some of their experiences and to scrutinise the narrative produced by the Trial Chamber judgment.

\section{Outlining the Background to Case 002/01}

Case 002 initially involved four defendants, Nuon Chea, Khieu Samphan, Ieng Sary and Ieng Thirith, who were indicted on 15 September 2010 on charges related to crimes against humanity, genocide and grave breaches of the Geneva Conventions of 1949. ${ }^{15}$ Following the death of Ieng Sary in March 2014 and Ieng Thirith being found unfit to stand trial in November 2011, there were concerns about the possible length of the case. ${ }^{16}$ Due to the frailty of the two remaining defendants and to expedite the trial to ensure a timely judgment, the Trial Chamber took the decision to sever case 002 into different parts (see Williams 2015). ${ }^{17}$ The first part, designated as case 002/01, was given a narrow focus on phase one and two of the population movements (the displacement from the capital Phnom Penh and other cities in April 1975 and the regional displacements perpetrated from September 1975 to 1977 ) as well as the crimes related to the Tuol Po Chrey execution site. ${ }^{18}$ The second part, case 002/02, is currently at the trial stage and involves further charges under the Closing Order in case 002. ${ }^{19}$

\footnotetext{
14 These 4 days of testimony were held between 27th May 2013 and 4th June 2013.

15 Co-Prosecutors v Nuon Chea, Ieng Sary, Ieng Thirith and Khieu Samphan, n 2 above.

16 Co-Prosecutors $v$ Nuon Chea, Ieng Sary, Ieng Thirith and Khieu Samphan, Decision on Ieng Thirith's Fitness to Stand Trial, Case File No 002/19-09-2007/ECCC/TC, 17 November 2011.

17 Co-Prosecutors $v$ Nuon Chea and Khieu Samphan, n 3, above.

18 ibid.

19 Co-Prosecutors v Nuon Chea, Ieng Sary, Ieng Thirith and Khieu Samphan, n. 2 above.
} 
The severance of case 002 has resulted in a paucity of academic focus on case $002 / 01$ and it seems that commentators are waiting for the outcome of the rest of case 002 (Williams 2014). However, academic engagement with case 002/01 is important, particularly as issues raised in the case may well be dealt with similarly in the remaining cases. The severance of the case raises issues concerning how the charges in case 002/01 and case 002/02 are addressed, whether the interrelationships between the harms involved in these cases will be reflected and the nature of the overall narrative produced by the judgments.

While case 002/01 is narrow in scope, it involved grave crimes related to the forced population movements and de-urbanisation of Cambodia. The evacuation of Phnom Penh and other urban areas, which constituted phase one of the population movements, began the same day (17th April 1975) as the fall of the city into Khmer Rouge control. The whole population of the capital city (between two to three million people) were forced to evacuate, regardless of sickness, infirmity or other vulnerabilities and the vast majority were not able to return to Phnom Penh until the regime's collapse in 1979 (Kiernan 2002). Phase two encompassed the forced displacement of the 'new people' (those previously displaced from urban areas) from the various regions to other worksites within Cambodia, between September 1975 and $1977 .^{20}$

The evidence has suggested a high death toll due to the harsh conditions, with perhaps as many as 10,600 deaths during the evacuation of Phnom Penh (Kiernan 2002, 48; see also Trial Chamber judgment, para. 521). During phase one of the population movements and their immediate aftermath, individuals were often unable to feed their children, as basic resources were not provided. Families were often separated as they were forced to leave immediately and were not allowed to search for family members, and many families have never been reunited. During phase two of the population movements, food was often not provided and the conditions during and after the displacements were frequently inhumane (Kiernan 2002). Families were also often separated, with individuals sent to different areas and worksites. The forced population movements involved the loss of homes and property, the dispersal of families and communities, the loss of previous livelihoods and ultimately often led to malnutrition and starvation in the worksites to which individuals and families were relocated. ${ }^{21}$ While the forced population movements do not immediately appear to have gendered elements, the article highlights the interrelationship between social harms and gendered experiences and the ways in which structural inequalities fed into experiences of the harms.

\footnotetext{
20 ibid.

${ }^{21}$ Harms related to the worksites will be dealt with in case $002 / 02$.
} 


\section{Exploring the Social Harms and Gendered Experiences of Forced Displacement}

Drawing on feminist theories of social harm (West 1997; Conaghan 2002; Ní Aoláin 2009), this section opens up some of the social and gendered experiences of familial separation and starvation of family members both as a basis for exploring experiences of harm and, in the last past of the article, for interrogating the narrative produced by the Trial Chamber judgment. In order to understand experiences of the forced population movements in Cambodia, it is crucial to move beyond a focus on physical harm to a holistic understanding that foregrounds the social nature of harm and reflects human relationships and connectedness.

\section{Exploring Feminist Understandings of Social Harm in Relation to Cambodia}

Feminist understandings of human interdependence have contested law's focus on the individual and on physical integrity harms. Feminist research has highlighted that harm is not simply experienced individually, as so often presented in law (West 1997; Conaghan 2002). Conaghan $(2002,322)$ has argued that, "although we tend to see harm as vested in the individual who sustains it, our concept of harm is thoroughly social". The social nature of harm is twofold; in terms of how social location impacts on who is affected by harm, as well as how experiences are mediated through social understandings of the harm involved (Conaghan 2002, 322). Rather than perceiving harm to focus predominantly on the individual, a social understanding of harm reflects the impact of harms on families, communities and social structures and how the social interrelates with and often shapes individual lived experiences (Ní Aoláin 2009, 224; Sankey 2015).

Understanding the relational nature of the self opens up the plurality and complexity of harm and the ways in which harm is understood and experienced through social meanings and relationships (Ní Aoláin 2009, 236). As Nedelsky (2011, 30) has argued, "what matters to individuals, and what matters about individuality, are best understood and fostered in relational terms". Relationships are central to the human experience, both in terms of intimate relationships with others and "social structural relationships, such as gender, economic relations, and forms of governmental power" (Nedelsky 2011, 4). Foregrounding the social nature of harm opens up the realities and contexts of lived experiences of violence, particularly of violence centred on the destruction of human relationships and on harms to loved ones, such as familial separation and starvation of family members.

The harms of forced displacement go beyond the physical, involving the "ways in which the family, the home, and communities are fractured socially" (Baines and Gauvin 2014). Indeed, forced displacement often involves a complex interrelationship between physical, psychological and social harms in terms of malnutrition, loss of health and well being as well as destitution, social dislocation and familial separation (Sankey 2015). Forced displacements not only remove the individual 
from a certain physical location, but also displace them from the home environment and often from communal and family structures and networks (Sankey 2015).

The forced population movements perpetrated in Cambodia were not simply experienced individually but were profoundly social. They involved not merely physical dislocation, but also social dislocation and often the separation of families. Indeed, social dislocation and familial separation were not only incidental features of the population movements, but often constituted part of a deliberate policy to rebuild Cambodia according to Khmer Rouge ideology (Mam 2004). Phase one set the scene for the implementation of worksites across Cambodia, while phase two often consolidated this process and further removed individuals from social support and survival networks through movement to different worksites. The harms therefore centred on disrupting or destroying human relationships and the social meanings underpinning such relationships.

The centrality of the family in pre-Khmer Rouge Cambodian society, and the prevalence of traditional gender roles determined social perceptions and meanings of the harm of familial separation. As Mam's research illustrates, "During the preKR period the family and the economic, cultural and religious institutions that supported it, formed the very foundation of Cambodian society. The KR attack on the family and its institutions thus threatened Cambodian society in a very fundamental way" (Mam 2004). The loss of family and community frequently meant a loss of social support structures and survival networks (Ye 2011). "Basic social networks of kinship and community were shattered; all loyalty was to be redirected to the Angkar" (Ledgerwood 2012, 68).

\section{The Relationship Between Gendered Experiences and Social Harm}

Social understandings of harm help to open up gendered experiences. Gender inequalities and social location impact on how harms of forced displacement are experienced and the social meanings underpinning the harms. In some situations women may be disproportionately affected by particular harms. In Cambodia, pregnant women and those who had recently given birth were particularly affected by the evacuation of Phnom Penh, due to the obvious difficulty and danger of the long journey and the inhumane conditions. In addition, supporters of the previous Lon Nol regime, particularly soldiers and civil servants, were immediately targeted for direct killings, meaning that a higher proportion of women may have been left to suffer phase one and phase two of the population movements (Ledgerwood 2012).

Experiences in Cambodia were also inevitably mediated through underlying gender inequalities and traditional roles within the family. "Even when women are suffering similar violations as men, they have a different impact on women, due to their pre-existing socio-economic and legal status, as well as the gender constructions in patriarchal societies" (Lemaitre and Sandvik 2014, 245). The forced displacements and subsequent separation of men, women and children into different work groups that occurred in many regions, prevented women from fulfilling traditional roles of looking after the home, caring for children and feeding their families (Mam 2004). Similarly, the population movements stripped men of their homes and previous livelihoods and thus their traditional roles of providing for 
their families. While policies differed across Cambodia, family separation seemed to be prevalent in many areas (Mam 2004).

This is not to argue that familial separation necessarily constitutes a more profound harm for women, as West (1997) has suggested, but rather that social contexts undoubtedly inform and shape lived experiences. In opening up such gendered experiences there is, however, the risk that perceptions of women predominantly as mothers and caregivers are reinforced and that traditional family structures are reified, rather than challenged (Ní Aoláin 2000). A social understanding of harm may therefore raise tensions from a feminist perspective in terms of the dangers of naturalisation of gendered roles and inequalities (Ní Aoláin 2000). While these dangers should not be underestimated, ignoring or marginalising gendered experiences is equally problematic. It is therefore important that in drawing out gendered experiences, the complexities of gender inequalities and roles are captured. Although understandings of human connectedness and relational approaches have tended to come from feminist perspectives, this should not mean that they are predominantly conceptualised in relation to women (Nedelsky 2011). Rather, drawing on an understanding of human connectedness opens up the complexities of human relationships and the ways in which underlying inequalities, including gender, shape experiences.

The traditional social positioning of women as mothers and wives in Cambodian society and of men as patriarchal fathers and providers for their families was an important factor that influenced experiences of forced displacement and familial separation. As Ní Aoláin $(2000,325)$ has highlighted in the context of the Holocaust in Europe, "Mothering is a gendered undertaking and is understood as such by those seeking to destroy the fabric of social life in a community ... Both psychological studies and individual testimonies demonstrate that women experienced forced separation from their children in profoundly different ways than did men".

While the context of Europe during the Holocaust is very different from that of Cambodia in the mid to late 1970s, similar gendered roles were evident (Natale 2011; Jacobsen 2008). Despite some movement towards gender equality in Cambodia in the early 1970s, particularly in urban areas, traditional gender roles were still very much embedded in society (Jacobsen 2008). As Mam $(2004,134)$ has highlighted, the separation of young children from mothers was particularly "awkward and unprecedented for the traditional Khmer family at that time ... During the pre-KR period, although grandmothers sometimes helped to ease the burden, child-care remained a mother's responsibility". The harm of separation from children therefore had particular social meanings in the Cambodian context, in terms of the negation of the social norms of childcare and traditional gender roles.

Indeed, the forced population movements instituted the Khmer Rouge's attempts to completely uproot and recreate Cambodian society, to change the nature of gender roles and to dismantle existing family structures (Jacobsen 2008; Mam 2004). The forced displacements were the first decisive step in forcing women and men from their homes and into an agrarian society. The population movements were therefore part of a process of dismantling existing social norms and structures. Nevertheless, despite Khmer Rouge claims to gender-neutrality, their policies were often not gender-neutral, nor did they institute gender equality (Jacobsen 2008). The 
regime may have outwardly endorsed a degree of gender equality, from which some female cadres may have benefited. Nevertheless, possibilities for women to attain equal status and power remained strictly limited (Jacobsen 2008, 218-219; Ledgerwood 2012, 70-71). It is therefore important to recognise the continuities in women's experiences of discrimination and violence before and during the regime, particularly within the family, but also the ways in which the violence of the Khmer Rouge regime constituted different forms of harm. The regime engendered the loss of traditional spheres of influence for many women, but often gave them little in return (Ledgerwood 2012, 69).

Harms of starvation of children and family members experienced during and in the aftermath of the forced population movements also had profound social meanings and implications. Social dislocation and familial separation limits the availability of social survival networks that are often central to the ability of individuals to access basic resources (Sankey 2015). Familial separation also negates the social role of food in maintaining family and communal bonds. While again mindful of the obvious dangers of essentialising women's experiences, it is important to note the very significant roles women traditionally play across many societies, including pre-Khmer Rouge Cambodia, in relation to food and feeding their families (Special Rapporteur on the Right to Food 2003, 7; Jacobsen 2008; Van Esterik 1999). The inability to feed family members, particularly children, therefore has particular gendered connotations.

The extent of the harms of the forced population movements, of familial separation and starvation of family members meant that Cambodian society as a whole was affected. Moreover, the psychological harms were inevitably infused with social meaning, as the violence centred on reconstituting society (Reicherter and Aylward 2011, 24). Psychological harm therefore cannot be understood in this context without foregrounding the social harm involved and the extent of societal trauma. Indeed, "if gendered experiences are to be recognized and addressed, more nuanced understandings of mental harm that better integrate social elements of harm may need to be explored" (Sankey 2015). Without an understanding of the social nature of harm and the centrality of family in pre-Khmer Rouge Cambodia, the experiences voiced in the oral testimony are liable to become lost or distorted.

\section{The Trial Chamber Judgment: Reflecting Social and Gendered Harms?}

Drawing on these insights, the last part of the article focuses on the Trial Chamber judgment. The judgment is undoubtedly significant in providing legal recognition of the scale and gravity of the forced population movements perpetrated in Cambodia (Williams 2014). Nevertheless, a deeper exploration, in conjunction with a reading of the civil party oral testimony, reveals its limitations. While familial separation and inhumane conditions experienced by family members were recognised in the judgment as grave crimes under international law, they were ultimately decontextualised, thus obscuring the centrality of the social harm and nuances in gendered experiences. Indeed, the limited gender awareness of the Court played out in the 
judgment in producing a predominantly gender-neutral account of the forced population movements.

\section{The Findings of the Trial Chamber and the Limitations of the Judgment}

The Trial Chamber found Nuon Chea and Khieu Samphan guilty of the crimes against humanity of murder, extermination, other inhumane acts (forcible transfer and attacks on human dignity) and persecution in relation to phase one and two of the forced population movements. ${ }^{22}$ The judgment confirmed that the crime of extermination can be perpetrated through "conditions of life aimed at destroying part of a population, such as withholding food or medicine" and that dolis eventualis constitutes sufficient mens rea (para. 416-417). This enabled the Trial Chamber to find that the inhumane conditions in which people had been moved during both population movements, which Khmer Rouge cadres knew would likely cause death of large numbers of persons, constituted extermination as a crime against humanity (para 562, 646-648). The Trial Chamber also found that the conditions imposed during both population movements constituted "serious attacks against human dignity and caused the victims serious bodily and mental harm" amounting to other inhumane acts of attacks against human dignity (para. 565; para. 644). The recognition that the forced population movements and the inhumane conditions suffered constituted crimes against humanity, and thus particularly grave harms, is undoubtedly important both for survivors and Cambodian society. As such, the significance of the judgment should not be underestimated.

Nevertheless, the narrative of the judgment suffers from the severance of case 002. While international criminal law necessarily fragments understandings of harm through dividing violence into the framework of the various international crimes, the severance of case 002 further fragmented understandings of the violence in Cambodia. The judgment was prevented from reflecting the ways in which the forced population movements related to other harms and thus from reflecting the long-term impacts of the forced displacements. Case 002/01 will need to be read in conjunction with the forthcoming judgment in case 002/02 and it would be a mistake to judge it too harshly at present, particularly as it is currently at the appeal stage and therefore not yet final.

However, the limitations of the judgment also stem from the failure of the Court to contextualise the violence in relation to Cambodia society, which may potentially be perpetuated in case 002/02. It is notable that despite being an internationalised tribunal, based in Cambodia, the Court failed to place the crimes within the context of Cambodian society at the time. Although the judgment gave considerable space to setting out the facts underlying the two phases of the population movements, it did not explore the context of Cambodian society in which these harms were perpetrated. While the Cambodian audience may be able to read this context into the judgment to some degree, it must be remembered that as a hybrid tribunal, the narrative of the judgment has wider significance for international law and for international understandings of the violence perpetrated in Cambodia. Moreover, as

${ }^{22}$ Co-Prosecutors v Nuon Chea and Khieu Samphan n. 4 above. 
a tribunal addressing historical crimes, contextualisation of Cambodian society at the time of the atrocities is all the more important.

Due to this lack of contextualisation, social harms and gendered experiences were frequently marginalised within the judgment. Significantly, the Court did recognise the particular difficulties and harms experienced by women in relation to pregnancy and childbirth during the forced population movements, under the crime against humanity of 'other inhumane acts' in terms of 'attacks against human dignity' (para 564). Indeed, in analysing the requisite elements of 'other inhumane acts' the Chamber cited the suffering of "the sick, the injured, the elderly, the pregnant and the young" (para 565). As such, the experiences of vulnerable members of society were recognised. However, aside from these highly visible gendered experiences, the judgment largely produces a narrative of the genderneutrality of the forced population movements.

The argument of the article is not that the Court ignored familial separation, but that the meanings of the harms involved were not explored or fully recognised. The judgment did recognise that families were separated during the forced population movements. Indeed, evidence that evacuees were "made to evacuate without all of their family members, were made to abandon weak family members along the way, or were separated from family members at checkpoints during the journey", was recognised under the crime against humanity of 'other inhumane acts' as 'forcible transfer' (para. 550). However, the impact of familial separation in a society where family structures had previously been paramount and where gender roles and inequalities remained embedded was not explicitly acknowledged.

While recognising that the elderly had to be abandoned by family members (para. 550), the harm was not contextualised in relation to Cambodian society, where elderly relatives were traditionally revered and taken care of by younger family members. Moreover, the gendered aspects of childcare and caring for elderly relatives were not recognised, meaning that the ways in which pre-existing gender roles impacted on experiences of familial separation and the social meanings of the harms involved was silenced.

The judgment also recognised that "Victims who were transferred, lost their homes, lost contact with family members, their surroundings, and their places of worship experienced a diminished sense of 'physical and spiritual security'. In particular, children who were displaced and thus taken away from their familiar surroundings lost the opportunity to interact with others, as well as the ability to plan for the future; they also faced difficulties settling into new and hostile surroundings" (para 523; see also para 582). It is significant that social dislocation is raised in the judgment in terms of people being forced to "re-socialise" following phase two of the population movements, thus illustrating that the Court had the potential to recognise these types of harms. However, the experience of social dislocation was not further explored or contextualised (para 582). In particular, the impact of the loss of community and social support networks on adults and the possible gendered nature of these experiences were not acknowledged.

Similarly, while the judgment recognised psychological harm to some degree, thus illustrating the Trial Chamber's awareness of harms other than physical violence, its approach remained limited. Significantly, it did acknowledge that "[i]n 
addition to physical trauma endured during their exodus, many Cambodians continue to suffer from anxiety as a result of having experienced great loss" (para. 522). Moreover, the Trial Chamber drew on the testimony of Dr Chhim Sotheara from the Cambodian Transcultural Psychosocial Organization, whose research has been focused on developing an understanding of trauma appropriate to the Cambodia context (Chhim 2012). Such evidence could have enabled the Court to reflect more fully on the relationships between social and psychological harm. Nevertheless, the space given in the judgment to the recognition of psychological harm was minimal and again, the harms were not contextualised in relation to Cambodian society (paras 522-524). The section on reparations allowed some further space for the acknowledgement of psychological harms. However, this part of the judgment largely repeated evidence it had previously cited, without further contextualising the harms involved (paras 1141-1150).

\section{Social Dislocation, Familial Separation and Harms of Starvation: Exploring the Civil Party Testimony}

In contrast, a reading of the civil party oral testimony reveals the centrality of social dislocation, familial separation and the harms of starvation of family members to many of these civil parties' experiences. It reveals how social meanings and gender norms infused experiences of the harms. While both male and female civil parties voiced the harm of familial separation and starvation of family members, it is possible to note differences in experiences in the oral testimony. In particular, the ages of the civil parties differed, such there were a larger number of female civil parties who experienced the Khmer Rouge regime at a time when they were already parents and spoke of their experiences of separation from and deaths of their children. Due both to these dynamics and the higher number of female civil parties who gave oral testimony on the population movements there are inevitably questions over the representative nature of the testimony. However, the aim is not to map out the harms of the forced population movements, but rather to explore such lived experiences in order to scrutinise the narrative produced by the Trial Chamber judgment and how the court drew on this evidence. Reading the judgment in conjunction with the civil party testimony thus highlights some of its limitations and the lost opportunities for contextualisation of the harms experienced.

Notably, the judgment drew extensively, both in the text and in the footnotes, on the civil party testimony in its examination of the offences perpetrated, meaning that the voices of the civil parties are evident. However, the ways in which the judgment drew on this testimony and the kinds of experiences it marginalised illustrate the limitations of its approach. Despite the number of female civil parties in the case, women's particular experiences were not explicitly reflected beyond the reproductive roles of pregnancy and giving birth and hence a focus on female vulnerability and biological difference. While female civil parties' testimony was documented and widely drawn on, it was integrated into the judgment in a way that largely elided how social structures and gender inequalities shaped lived experiences.

As such, the judgment did not open up how gender intersected with other identities in shaping experiences, other than a broad recognition of the demarcation 
enforced by the Khmer Rouge between the 'base' and the 'new' people (para. 656). Indeed, it is notable that while the judgment drew quite extensively on Ms Sou Sotheavy's testimony (27 May 2013), it silenced her transgender identity and ignored the particular harms she voiced as a transgender woman. Although Ms Sou Sotheavy (p. 11 and 18) spoke explicitly of her experience of being displaced alongside other transgender people and of the discrimination she faced following the forced population movements due to her gender identity, these elements of her testimony were ignored.

Familial separation constitutes a recurrent harm voiced through much of the civil party oral testimony. Fourteen of the civil parties who gave oral testimony spoke directly of their own experiences of familial separation either during or in the aftermath of the forced population movements. In addition, some of the civil party oral testimony referred to the horror of the evacuation and how they witnessed other families, particularly children, lost and separated in the confusion (see, for example, Ms Po Dina 30 May 2013, 100). The testimony provides insights into the devastating experiences and the social and cultural meanings of familial separation, and provides the contextualisation of the violence that the judgment often lacks.

The centrality of familial separation and social dislocation to the harms of the forced population movements is evident in the testimony:

During the evacuation from Phnom Penh on 17 April 1975, it could be compared to a bomb [sic] was exploded to shatter all the families in Phnom Penh. We separated from one another in a sudden movement. We separated from family members, from friends, and we suddenly lost all what we earned and all the properties we lost. We did not get news from them; some of them even until today and in around September 1975, I was by myself far away from my native village, from my family members and from my close friends (Ms Toeng Sokha 4 December 2012, 98).

Much of the testimony that voices familial separation dwells on the loss of community structures and relationships, and on their profound social and psychological impacts (see, for example, Ms Sang Rath 27 May 2013, 60 and Ms Chan Socheat 29 May 2013). As Ms Sophan Sovany (30 May 2013, 54) related, "we had to separate from one another in the family and this separation was suffering. We did not have any food to eat and we had to leave, stay away from our parents and our beloved brothers and sisters. This was the tragedy in our life".

Ms Mom Sam Oeurn (6 November 2012, 20) related the shattering of her family structure during her testimony: "they separated my kids from me; all of my kids were separated". The testimony also provides insights into the social meanings underlying these harms and the ways in which separation broke social norms. As one civil party explained, "children were forced to leave their parents behind and you know that we worship our parents. Parents are very sacred to us and when we saw parents separate from their children, it was something that was extremely, extremely hard for Cambodian children” (Ms. Thouch Phandarasar 29 May 2013, 9).

While some familial separation occurred as a result of or immediately after phase one and two of the population movements and thus came within the scope of the 
case, some of the separations occurred later and thus fall more clearly within the scope of case 002/02. As such the severance of the case prevented some of the testimony from being reflected in the judgment. The severance therefore presents an artificial division between immediate and subsequent familial separation, which fails to reflect the ways in which the forced population movements fed directly into experiences of separation by laying the foundations for separation on the worksites. However, even where such testimony clearly relates to separation during and immediately after the forced population movements, the judgement does not reflect the social context surrounding these harms and their meanings, as expressed by the civil parties.

The testimony also strongly reflects the harm and trauma of deaths stemming from the harsh conditions of the forced population movements. However, while the judgment recognises the harsh conditions and the deaths, it fails to fully capture experiences of the harms themselves and in particular the social nature of the harm. Again, while the severance of the case prevented the judgment from integrating testimony relating to later starvation in the worksites, the judgment also suffers from the de-contextualisation of the harms when outlining deaths immediately following the population movements. Moreover, much of the testimony highlights how isolation and separation violated the social norms of Cambodian society, evidence that the Court could have reflected on when outlining the harm of familial separation and loss of loved ones directly stemming from the forced population movements.

The inability to provide food for family members during and after the forced population movements, and thus fulfil family responsibilities and gender roles, resonates throughout much of the oral party testimony as a particularly traumatic harm, illustrating the sense of the relational self. While the loss of children through any means is profoundly traumatic, such testimony illustrates the particular harm of witnessing your children dying of starvation or inhumane conditions and being unable to prevent it. For example, Mrs Denise Affonço (13 December 2012, 104-105) related that, "When you see your daughter dying of hunger, and she says, "Mommy, can I have a bowl of rice?", and I was never able to give her that bowl of rice before she died, then I can tell you I have undergone harm" (italics added). In addition, Ms. Thouch Phandarasar's testimony reflects profound feelings of guilt regarding the inability to care for elderly parents, as required by Cambodian society. "I retain a terrible feeling of guilt about this; not having been able to save my parents ... You never erase memories like that and that's why I'm here to ask this Court for justice" (Ms. Thouch Phandarasar 29 May 2013, 13). While such testimony reflects personal feelings of guilt it also reflects gendered dimensions of caring in Cambodian society, a context that the judgment does not acknowledge.

Some of the testimony also expresses deep feelings of loss and social dislocation following the death of loved ones, providing important insights into the complex social and psychological harms experienced, on which the judgment could have drawn. Ms Po Dina (30 June 2013, 105) related that "[m]y life is like a woman in the Cambodian folk tale that I lost everyone; my husband, my mother and my son. I no longer had any hope with me. My life would become meaningless as all the valuables to my life-that is, my beloved ones, all left". Relating the trauma to this 
Cambodian folktale reveals the social meanings infused in these experiences and illustrates the centrality of family and community to Cambodian society and the particular (gendered) harm of being left by oneself. Ms Sang Rath (27 May 2013, 60) similarly related that "I was like an old woman in a Khmer folktale, Badacha; it means I'm by myself'.

The social meanings underlying the harm of isolation of children are also evident in some of the testimony. As Mr Aun Phally (27 May, 2013, 36), who was a child at the time of the regime, related, "I considered myself a strange person that I lived by myself with no relatives". While this testimony goes beyond the scope of the forced population movements it could possibly have been drawn on to explore how feelings of social dislocation were entwined with psychological despair and emotional emptiness and how destruction of relationships can collapse an individual's sense of meaning and purpose. As Ms Huo Chantha (29 May 2013, 81) expressed, "I was despaired. I find that I was useless; I had no family members; my parents were all gone. I look at everything around me, everything was meaningless for me; my life is completely meaningless". It is therefore hoped that such testimony is reflected on and explored in the remaining parts of case 002.

\section{Addressing Gendered Harms at the ECCC: Questions of Feminist Strategy}

Thus, although the Trial Chamber's recognition that the forced population movements involved separation of families is of itself significant, the judgment represents a lost opportunity to surface the social and gendered nature of the harms. It highlights that even when women are able to participate as civil parties and to voice their experiences in criminal justice processes, these experiences may not be fully heard by the Court (SáCouto 2011). International(ised) criminal tribunals constitute imperfect tools for the narration and recognition of harm, and particularly of gendered experiences (Buss 2014; O'Rourke 2013). Legal responses to harm inevitably bring certain meanings and practices to bear that may render harm both visible and invisible (Buss 2009).

International(ised) criminal tribunals therefore obscure many of the contexts and wider experiences of harms that may enable an understanding of social harms. In particular, the relationship between structural inequalities and experiences of mass violence may be silenced by the focus on extraordinary instances of political violence. Indeed, international criminal law has tended to focus on bodily violence to the exclusion of other forms of harm, including social harm (Nagy 2008). While international criminal law recognises group harm, most obviously under genocide and crimes against humanity, the law largely fails to reflect and incorporate an understanding of relationships and human connectedness (Ní Aoláin 2009).

The tension, highlighted earlier, between the recognition of the impact of gender inequalities and the dangers of essentialism therefore raises particular challenges for legal recognition of harms and experiences. Ní Aoláin (2000, 325) has thus questioned "whether legal sanction should reflect the reality of the actual practices, even though identifying them as harms may bolster their embeddedness as social norms. Or should the legal sanction conform to the ideal type of self, unencumbered by social context?" The danger of the latter approach is that legal processes produce 
a narrative of the gender-neutrality of violence, which fails to reflect and contest structural inequalities in the particular society. In arguing for greater recognition of social harms there is therefore a need to be alert to the potential of legal processes to essentialise gendered harms and silence the plurality of experiences, and to contest such representations.

Although it is impossible for any judgment to condense and reflect the complexity of victim and witness testimony, the ECCC could have attempted to set out the context of pre-Khmer Rouge society in discussing the nature of the violence. Doing so would have resulted in a judgment that more fully captured and reflected evidence of victims' experiences, without impacting on the rights of the accused. Such contextualisation would not have made a difference to the verdict, but it would have provided a fuller account of the violence of the forced population movements and the nature of the harms involved. As Ní Aoláin (2000) has argued more generally, 'unless international legal prohibitions can address the totality of harm experienced by the victim, prohibitions will fail to produce any meaningful form of accountability'. While such complexity is obviously difficult for any tribunal to fully grapple with and reflect, international crimes of whatever type are inevitably complex. International tribunals are perpetually presented with social, political and cultural complexity, such that greater recognition of the complex social harms should not be deemed to be particularly unrealistic.

International and hybrid criminal tribunals play an important expressive and performative role in narrating and recording past violence, judging harms as well as providing an agenda for 'transition' in the society concerned (Buss 2011). The types of harms named and recognised within these tribunals feed into and inform the nature and terms of the transition. Recognition of the social complexity of harm is thus important both in reflecting lived experiences and in promoting attention to social and gendered inequalities in the transitional society. While this role is perhaps less apparent in the Cambodian context, as a situation of historical political repression, the ECCC will necessarily play a part in producing a narrative of the Khmer Rouge regime, shaping understandings both in Cambodia and internationally, and promoting certain responses to the on-going experiences of survivors.

Indeed, the historic nature of the crimes addressed by the Court mean that it is all too easy for the work of the ECCC to be distanced from contemporary experiences of harm and inequality. The terms of transition are focused narrowly on accountability for Khmer Rouge atrocities, rather than incorporating a broader agenda of societal change and transformation. Adopting a more contextual approach to the harms perpetrated and reflecting the social complexity of harm would be an important way for the Court to open up a contemporary discourse in Cambodia around the nature of harm and inequality, while remaining within the confines of its statute. As a hybrid tribunal, the Court's judgment may also influence wider understandings of the harms of forced displacement and starvation in international criminal law, meaning that the marginalisation of social harms and gendered experiences may be perpetuated in other tribunals.

The largely gender-neutral approach of the Trial Chamber judgment in case 002/01 served to marginalise the particular experiences of women and closed down a space for broader societal discourse on issues of gender equality. Indeed, given 
Khmer Rouge claims regarding the equal treatment of men and women, the dangers of producing a narrative of gender-neutrality are all the more significant in the Cambodian context. It is particularly important that in case 002/02 the Court does not accept Khmer Rouge claims regarding gender equality, but interrogates and opens up the gendered nature of the violence perpetrated and the ways in which shifts in gender relations under the regime interacted with pre-existing inequalities to shape lived experiences.

\section{Conclusion}

The article has argued for the importance of a social understanding of harm in order to reflect gendered experiences in Cambodia. However, it has also highlighted the ways in which social harms and gendered experiences may be elided by international(ised) criminal tribunals. Even when survivors are permitted to testify as civil parties and where women constitute the majority of these civil parties, courts may still not fully hear and reflect the complexities of harms. Case 002/02 provides the ECCC with further opportunities to develop a more contextual approach that encompasses the social elements of harms of the Khmer Rouge regime, which it is hoped the Court will adopt. As such there is a need for further feminist scrutiny of the Court and research into the social nature of harms experienced in Cambodia. Providing "justice" means rendering visible the impact of underlying inequalities and social contexts on the harms of the Khmer Rouge regime, in order to both reflect lived experiences and challenge on-going violence and inequality. In decontextualising the harms and often eliding the social and gendered elements, the Court closes down opportunities to promote a more meaningful and transformative form of justice for Cambodia and its people.

Acknowledgments I would like to thank the Society of Legal Scholars for the funding given to support this research. I would also like to thank the two anonymous reviewers for their helpful suggestions, as well as Dr Emily Haslam for her support and comments on a previous draft.

Open Access This article is distributed under the terms of the Creative Commons Attribution 4.0 International License (http://creativecommons.org/licenses/by/4.0/), which permits unrestricted use, distribution, and reproduction in any medium, provided you give appropriate credit to the original author(s) and the source, provide a link to the Creative Commons license, and indicate if changes were made.

\section{References}

Baines, Erin, and Lara Rosenoff Gauvin. 2014. Motherhood and social repair after war and displacement in Northern Uganda. Journal of Refugee Studies 27(2): 282-300.

Boua, Chanthou. 1982. Women in today's Cambodia. New Left Review 131: 45-61.

Buss, Doris E. 2009. Rethinking 'Rape as a Weapon of War'. Feminist Legal Studies 17: 145-163.

Buss, Doris. 2011. Performing legal order: Some feminist thoughts on international criminal law. International Criminal Law Review 11(3): 409-423. 
Buss, Doris. 2014. Knowing women translating patriarchy in international criminal law. Social \& Legal Studies 23(1): 73-92.

Chhim, Sotheara. 2012. Baksbat (broken courage): The development and validation of the inventory to measure baksbat, a Cambodian trauma-based cultural syndrome of distress. Culture, Medicine and Psychiatry 36: 640-659.

Conaghan, Joanne. 2002. Law, harm and redress: A feminist perspective. Legal Studies 22(3): 319-339.

de Langis, Theresa. 2014. A missed opportunity, a last hope? Prosecuting sexual crimes under the Khmer Rouge Regime. Cambodia Law and Policy Journal 2: 61-78.

Dembour, Marie-Bénédicte, and Emily Haslam. 2004. Silencing hearings? Victim-witnesses at war crimes trials. European Journal of International Law 15(1): 151-177.

Elander, Maria. 2013. The victim's address: Expressivism and the victim at the Extraordinary Chambers in the Courts of Cambodia. International Journal of Transitional Justice 7: 95-115.

Franke, Katherine. 2006. Gendered subjects of transitional justice. Columbia Journal of Gender and Law 15(3): 813-828.

Harris Rimmer, Susan. 2010. Sexing the subject of transitional justice. Australian Feminist Law Journal 32: $123-147$.

Hoven, Elisa. 2014. Civil party participation in trials of mass crimes: A qualitative study at the Extraordinary Chambers in the Courts of Cambodia. Journal of International Criminal Justice 12: 81-107.

Jacobsen, Trudy. 2008. Lost goddesses: The denial of female power in Cambodian history. Copenhagen: Nordic Institute of Asian Studies.

Kiernan, Ben. 2002. The Pol Pot Regime: Race, power, and genocide in Cambodia under the Khmer Rouge, 1975-1979. New Haven: Yale University Press.

Killean, Rachel. 2015. An incomplete narrative: Prosecuting sexual violence crimes at the Extraordinary Chambers in the Courts of Cambodia. Journal of International Criminal Justice 13: 331-352.

Ledgerwood, Judy. 2012. Death, shattered families, and living as widows in Cambodia. In Plight and fate of women during and following genocide, ed. Samuel Totten, 67-81. London: Transaction Publishers.

Lemaitre, Julieta, and Kristin Bergtora Sandvik. 2014. Beyond sexual violence in transitional justice: Political insecurity as a gendered harm. Feminist Legal Studies 22: 243-261.

Mam, Kalyanee. 2004. The endurance of the Cambodian family under the Khmer Rouge regime: An oral history. In Genocide in Cambodia and Rwanda: New perspectives, ed. Susan E. Cook, 127-171. London: Transaction Publishers.

McGonigle Leyh, Brianne. 2012. Victim-oriented measures at international criminal institutions: Participation and its pitfalls. International Criminal Law Review 12: 375-408.

Meertens, Donny, and Margarita Zambrano. 2010. Citizenship deferred: The politics of victimhood, land restitution and gender justice in the Colombian (post?) conflict. International Journal of Transitional Justice 4(2): 189-206.

Nagy, Rosemary. 2008. Transitional justice as global project: Critical reflections. Third World Quarterly 29(2): 275-289.

Nakagawa, Kasumi. 2008. Gender-Based Violence during the Khmer Rouge Regime: Stories of Survivors from the Democratic Kampuchea (1975-1979). Phnom Penh: Cambodia Defenders Project.

Natale, Katrina. 2011. "I could feel my soul flying away from my body": A study on gender-based violence during Democratic Kampuchea in Battambang and Svay Rieng Provinces. Phnom Penh: Cambodia Defenders Project.

Nedelsky, Jennifer. 2011. Law's relations: A relational theory of self, autonomy, and law. Oxford: OUP

Ní Aoláin, Fionnuala. 2009. Exploring a feminist theory of harm in the context of conflicted and postconflict societies. Queen's Law Journal 35: 219-244.

Ní Aoláin, Fionnuala. 2000. Rethinking the concept of harm and legal categorizations of sexual violence during war. Theoretical Inquiries in Law 1: 307-340.

Ní Aoláin, Fionnuala, Dina Francesca Haynes and Naomi Cahn. 2011. Criminal Justice for Gendered Violence and Beyond. International Criminal Law Review 11(3): 425-443.

O'Rourke, Catherine. 2013. Gender politics in transitional justice. Abingdon: Routledge.

Reicherter, Daryn, and Alexandra Aylward. 2011. The impact of war and genocide on psychiatry and social psychology. In Cambodia's hidden scars: Trauma psychology in the wake of the Khmer Rouge, ed. Beth Van Schaack, et al., 14-27. Phnom Penh: DCCAM. 
SáCouto, Susana. 2011. Victim participation at the International Criminal Court and the Extraordinary Chambers in the Courts of Cambodia: A feminist project? Michigan Journal of Gender \& Law 18(2): 297-359.

Sankey, Diana. 2015. Gendered experiences of subsistence harms a possible contribution to feminist discourse on gendered harm? Social \& Legal Studies 24(1): 25-45.

Sperfeldt, Christoph. 2013. From the margins of internationalized criminal justice: Lessons learned at the Extraordinary Chambers in the Courts of Cambodia. Journal of International Criminal Justice 11(5): 1111-1137.

Stegmiller, Ignaz. 2014. Legal developments in civil party participation at the Extraordinary Chambers in the Courts of Cambodia. Leiden Journal of International Law 27(2): 465-477.

Studzinsky, Silke. 2013. Victims of sexual and gender-based crimes before the Extraordinary Chambers in the Courts of Cambodia: Challenges of rights to participation and protection. In Sexual violence as an international crime: Interdisciplinary approaches, ed. Anne-Marie de Brouwer, et al., 173-186. Cambridge: Intersentia.

Van Esterik, Penny. 1999. Right to food; right to feed; right to be fed: The intersection of women's rights and the right to food. Agriculture and Human Values 16: 225-232.

Wallström, Margot. 2012. The forgotten Khmer Rouge victims. Phnom Penh Post, May 29.

West, Robin. 1997. Caring for justice. New York: New York University Press.

Williams, Sarah. 2014. The conviction of Cambodian Khmer Rouge leaders-Justice at last? EJIL Talk. http://www.ejiltalk.org/author/swilliams/. Accessed 12 Feb 2015.

Williams, Sarah. 2015. The severance of case 002 at the ECCC: A radical trial management technique or a step too far? Journal of International Criminal Justice 13: 815-843.

Ye, Beini. 2011. Forced Marriages as Mirrors of Cambodian Conflict Transformation. Peace Review: A Journal of Social Justice 23(4): 469-475.

Ye, Beini. 2014. Transitional Justice Through the Cambodian Women's Hearings. Cambodia Law and Policy Journal 3: 23-38 